\title{
ARCHETYPE OF PATRIARCHY IN SAHAR KHALIFEH'S WILD THORNS
}

\author{
Saqer Salameh Ahmad Sahmasin Khresheh ${ }^{1}$ \\ Faculty of Languages \& Communication, University Sultan Zainal Abidin. \\ (Email: saqerbinsalameh@yahoo.com) \\ Dr. Ady Radwan ${ }^{2}$ \\ Faculty of Languages \& Communication, University Sultan Zainal Abidin. \\ (Email: radzuwanrashid@unisza.edu.my)
}

Received date: 11-09-2019

Revised date: $21-10-2019$

Accepted date: 01-11-2019

Published date: 05-12-2019

To cite this document: Khresheh, S. S. A. S., \& Radwan, A. (2019). Archetype of Patriarchy in Sahar Khalifeh's Wild Thorns. International Journal of Humanities, Philosophy and Language, 2(8), 109-115.

DOI: $10.35631 /$ ijhpl.28008

\begin{abstract}
Wild Thorns by Sahar Khalifeh emphases on the Zionist occupation of Palestine. It reflects the Zionist occupation as patriarchy. This research aims at inspecting the type of occupation that has been symbolized in the form of patriarchy in Wild Thorns. The research has been directed depending on Jungian criticism that interprets literature as a source of "archetypes". Therefore, the research aims at interpreting the archetype of patriarchy proposed in Freud's Totem and Taboo. Depending on this theory, humanity experienced father dominance over children and wives. Accordingly, a revolution or resistance by children and wives is justified due to the bad deeds imposed by the father dominance. In such a way, Patriarchy is embodied in Wild Thorns by the depiction of the relationship between the occupier and the occupied that enables Israel to play the role of a father who imposed bad regulations that made people live in Palestine difficult.
\end{abstract}

Keywords: Archetype, Totem and Taboo, Sahar Khalifeh, Wild Thorns

\section{Introduction}

The appearance of the Palestinian fictional literature includes two central periods: the first represented the years after Alnakbah (when Zionists first occupied Palestine except the West bank), 1948, and the second represented the years after Alnakasah, (when Zionist occupied the West bank including Jerusalem), 1967, (Zalman, 2003, p.1). The appearance of female Palestinian writers notably belongs to the second period, after 1967, "most men were crippled by a sense of defeat, so women were the first to carry the burden" (Sabbagh, 1989, p.62). Among those female writers is Sahar Khalifeh who is: 
One of the prominent novelists born in Nablus and has become well known for her feminist stances. As a very young woman, she entered into a traditionally arranged marriage; then, after thirteen years of frustration and disappointment, she found her freedom and decided to dedicate herself to writing. She resumed her studies and obtained a PhD from the University of Iowa in 1988 in Women's Affairs Center in Nablus and Gaza. Sahar Khalifeh has written five novels so far and her early novel, We Are No More Your Slave Girls, made quite an impact because of its advocacy of feminist freedom. However, it was with the appearance of her third novel, Wild Thorns in 1979 that she received literary recognition and acclaim (Jayyusi, 1992, p.589).

This research inspects Wild Thorns according to a psychological critical approach where literary works are shown and investigated as "an expression of the state of the mind" (Abrams, 1999, p.247). Consistent with Freud's psychology, literary works ascend from the requirements that "are repressed by the censor into the unconscious realm of the artist mind but are permitted by the censor to achieve a fantasied satisfaction in distorted forms" (Abrams, 1999, p.247). Thus, discussing literary works from a psychological point of view is justified and permitted. Actually, the central reason for selecting Wild Thorns was that the researcher sees it as a novel ascending from a pure and clean experience of the author. Because of this, it is appropriate to be investigated from psychological point of view.

The novel theme describes the return of Usama al-Karami after five years and his observation of changes happened during his years of absence. He found that Palestinians have no right to farm their lands or to work in their country and he found them work as slaves in occupiers' farms and organizations. From this point he started to feel that his people are no longer able to fight the occupier and accept the new condition of the country under occupation. As a reaction of what he witnessed and found, he started his burden to warn and encourage people to be aware about the Palestinian cause and to resist against this kind of slavery. He reminded people around him of the responsibility of them toward the coming generation who if they see the current condition of their ancestors, they will act the same toward the cause and consequently Palestine will be lost. To activate his warns to his people he decided to blow the bus that moves Palestinian labors in Israel.

The story is also about the family Usama's uncle, Karam who is overconfident and ill. Karam eldest son, Adil, found himself obligated to work the whole day to earn money that are needed for his father treatment. Karam daughter, Nuwar, fallen in love of a Palestinian fighter named Saleh without expressing her love because of her fears from her father. A rebellion son of Karam, Basil, joined Usama and assisted him in implementing his plan. We can touch her that the two sons and the daughter are not in a good relationship with their father because their relationship with their father was built on the idea of fear not on the idea of respect. No one is happy of his condition. Most notably, the relationship between the father and Basil who didn't hesitate to show his rejection of every order from the father as when he rejected his father order about marrying Nuwar to Doctor Ezzat AbdolRabah. As a result of Basil rejections, the father health got worse hospitalized. Exactly as the bad behavior of the father led his sons and daughter to resist against his orders and hope death to him, Palestinians rejected racial policies of Zionists and resisted for the occupation death.

\section{Literature Review}

Sahar Khalifeh has been a major focus of several articles, especially in the nineteenth century. Some of these articles specifically analyze the representations of Palestinian identity while others focused on various topics across the globe. For instance, Ebileeni (2017) reviewed 
some studies on Palestinian writings in the world specifically polylingual literary category and compared them to local and transnational realms. The study focused on the Palestinian issues and possible implications inherent in the literary works of the US, UK, and Israel written by Palestinian authors. Because of their day-to-day commitment to different languages of the local masses, literature from these distinctive environments is usually described by the writer's efforts to preserve the cultural boundaries and discover the national identities both against the backdrop and under the power of external cultural elements.

According to Priyanka and Koudur (2018) Khalifeh basically appeals to the obstacles and weaknesses in resistance strategies while fighting against the Zionist colonization. This idea is confirmed by Khalifeh herself as quoted in Jaber (2009) when she exposed that the Palestinian people were born in the area of blood and weakness. The main aim of Palestinian resistance is to communicate their ongoing struggle through different ways of expressions to the rest of the world, in order to avoid Western and Israeli misrepresentation of Palestinian resistance movement, limiting their struggle only to terror symbols. Khalifeh portrays the collective and group violence perpetrated by both Palestinians and Israelis in the wake of resistance movement. However, in the last decade there was an alarming increase in the use of violence from both sides. Khalifeh 's novels mirror the various ways in which power had been exercised by colonizers and resisted by the natives. Palestinian resistance is inevitably taking new turns throughout the vicious period of colonial domination, from non-violence to violence, from community to individual orientation and from the Islamic to the secular or the religious to the non-religious. These multiple strategies articulate the acute urge among Palestinians to fight against Israeli occupation in order to survive.

\section{Theatrical Framework}

For investigating and analyzing the selected novel, the researcher used Jungian approach that is adopted by Carl Gustav Jung about the theory of collective unconscious. He considers the human psyche is composed of the collective unconscious that "retains and transmits the common psychological inheritance of mankind" (Jung, 1988, p.107). He sees the collective unconscious as "the repository of racial memories and of primordial images and patterns of experience forms that he calls archetype" (Abrams, 1999, p.251). In addition, He claims that the transferred experiences and archetypes "function, when the occasion arises, in more or less the same way in all of us" (Jung, 1988, p.75). Thus, he sees that man has continuously dealt with archetypes during history circle that demonstrated themselves in different means including literature. So, it is significant to inspect literature from this angel where every literary work may possibly grasp archetypes that man transfers to generations. Depending on the theory, Wild Thorns as a literary work may possibly be inspected from the viewpoint of archetypal criticism. Regarding the archetype that is going to be examined in the selected novel, it will be the archetype of patricide.

Sigmund Freud claims that the archetype of patricide refers to the period before the history. He says that "a scenario where, long ago, people lived in primal hordes governed by an autocratic father. The patriarch kept the women for his sons, from sharing in his delights" (Heller, 2005, p.205). In this original flock situation "there was domination by the old male over females, and over his expelled sons. This was the first patriarchal society" (Bocock, 2002, p.66). Accordingly, children and wives are disappointed and frustrated to the degree that "one day the brothers who had been driven out came together, killed and devoured their father and made an end to the patriarchal horde. United, they had the courage to do and succeed in doing what would have been impossible for them individually" (Freud, 2001, p.141). According to Freud, this original patricide left its influence on the way humanity 
thinks and "the murder was so traumatic that permanent memory trace was laid down in the human race a phylogenetic inheritance" (Lear, 2005, p.213). Therefore, the issue of patricide "was a real event which had left ineradicable traces in the history of humanity (Storr, 1989, p.107).

\section{Discussion}

Indeed, Patricide archetype in the Wild Thorns is embodied in two different faces. First, it is embodied in the way Israel practices the father authority on the Palestinians who, as a reaction, will resist and hope death to the occupation. Second, it is embodied in the way Karam practices the father authority on his children who, as a reaction, resist and hope death to him and that are actually what happened when Adil decided not to take his father's treatment and machine with him when the soldiers asked him to leave the house in ten minutes. Here, we can infer that Israeli strategy of preventing Palestinians from working on their lands and lead them to work in Israeli factories is similar to the bad authority of fathers in preventing children from choosing what they like and from sharing their ideas with him. This is actually one of the ideas Khalifeh deals with in Wild Thorns, as she depicted "Palestinians began to abandon their land for work in Israeli factories, for seeking better wages" (Abu-Shamsieh, 1987, p. 344). This is similar to what the patriarch father used to do in original hordes to "expel his younger male rivals, for preventing incest" (Storr, 2001, p.106). So, imposing Israeli dominance on Palestine explains the reason behind castrating and expelling Palestinian youth as depicted throughout the novel. A clear example forms the novel is shown when Usama is in a taxi on his way to Nablus and his conversation with AbuMuhamad. Abu- Muhamad told Usama about his immigrant sons to Arab countries except Khalid who was about to be killed by Israeli soldiers:

Khalid is the last of the line and of the six, he is the only one who's been a problem. He got out of prison on bail. They had tortured him in every part of his body, even down there. They loused a dog on him that went for his genitals. He may be infertile. You mean impotent (Khalifeh, 2005, p. 7).

The second face of patricide is exposed in Palestinian society and the family system. Khalifeh sees that the main patriarchal system in Palestine is the basic reason behind failure in defending the cause. She claims that "In Wild Thorns, most of the main characters are male at the time reality seemed male" (Johnson, 1990, p. 24). She first criticized the male-centered society and sees it as a reason behind what Arab lost in 1967 war. She sees that first we have to forget this patriarchal system if we want to move toward freedom. This is what clearly shown in Adil speech when he says, "the decrepit house of ours produces nothing but illness and cowardice" (Khalifeh, 2005, p.193). Moreover, Basil, comments on this idea when he says, "I am a stranger in this house, damn this house" (Khalifeh, 2005, p.199). What makes this argument of Khalifah reasonable is the way she depicts Karam as a dependent and sick father, but still practices his dominance with fully ignorance of his condition exactly as Palestine is. So, freedom of Palestine is related and condemned by the change of Patriarchal system. To expose this dominance brilliantly, Khalifah distinguish him with a special way of naming by giving him the name of Alwaled that means the father without mentioning him in his given name as the other characters are. This way what explains his superior position compared to the others:

The father always wants to impose his sovereignty on the other members of the Karamis family and constantly exerts his dominance on his children, as the character of Nuwar expresses in a part of the novel "father was bellowing for Basil who reluctantly went into his 
bedroom. Another shout, this time for his wife. She left what she was doing in the kitchen and went into him" (Khalifeh, 2005, p.191).

To confirm this idea Khalifeh depicted Adil and his siblings frustrated their father behavior and system. For Adil, eldest son, he is wasting his years in working from the morning till the night to earn money to bear the expenses of his father's dialysis, he comments on that:

And that damned kidney machine's never satisfied. A mouth as big as the gates of hell sucks up money to keep my father's bones alive. While my revered father continues to sit on his throne in the reception room surrounded by the notables (Khalifeh, 2005, p.55).

Moreover, Basil, the other son, is also distressed and disappointed by his father's behavior and states that clearly in monologue, "I hate my father because he personifies sickness" (Khalifeh, 2005, p.199). In addition, the only daughter, Nuwar, also sees her father as useless and has nothing to do except make the lives of his children as a hell, "What does he do, may I ask, she said bitterly, 'except make our lives hell” (Khalifeh, 2005, p.199).

As a result of this Patriarchal system shown by the fathers' behaviors invited the children to be united against him by the end of the novel. This alliance between them is exposed firstly when father presents the proposal of Dr.Abd-AlRabbah to Nuwar. This proposal was rejected by Basil and this is what made the father health worst:

Then, without warning, he heard himself speaking solemnly and slowly as though reading a formal statement. He said "Nuwar al-karami loves Salih al-Sfadi but won't admit it. She's promised to wait for him as long as he's in prison. That's assuming the occupation continues, of course. If the occupation ends, she plans to marry him no matter what all of you say. And most of all, no matter what her father says (Khalifeh, 2005, p.199).

This alliance progresses as the novel progresses arriving at the point that convince Adil to reject and rebel against his father dominance. This rejection of Adil is translated at the end of the novel when Adil decided not to bring his father's dialysis machine after the warring of Israeli soldiers to take the necessary things within ten minutes before demolishing the house because of Basil deeds, "I won't take that damn machine. Yes, I will. No, I won't. Yes, I will" (Khalifeh, 2005, p.203). This hesitation continues and the internal conflicts progresses to the point Adil convinces himself that he is doing the family a favor by killing his father:

Adil, for God's sake, be decisive. For once be decisive in your life! Emotions won't help you. Would you kill a man then? Kill your own father! But men are always killing. And if my father goes on living, we'll all die. Me, Nuwar, the children (Khalifeh, 2005, p.173).

In Wild Thorns, Khalifeh deliberates the Palestine cause by opposing two types of patriarchies. The first patriarchy is the Zionism that colonized Palestine and then attempts to torture and dismiss the Palestinian youth to strengthen its dominance. The second is the patriarchy in the Palestinian family system that accidentally helps the occupiers to broaden its dominance. According to Khalifeh, no solution for the Palestine cause without finding a solution for the Patriarchal system in Palestinian family. As stated earlier, this pint of view is exposed through the alliance between the children of Karam; Basil and Nuwar firstly fire the situation and make their father hospitalized by rejecting his proposal toward Nuwar engagement then, Adil decision of leaving the dialysis machine in demolished house. So, we can say that the basis of the Palestinians' family system is a type of Totemism that is 
"replaced by newer forms" (Freud, 2001, p.31). In such a way the children rejection of bringing the machine symbolizes the rejection of Arabs traditions regarding the social system including family system. Here, Khalifeh sees that the victory could not be achieve regarding the Palestinian cause without eliminating the father's tyranny from the family system:

I could see very clearly that the debacle of 1967 was the fruit of a rotten tree that needed a cure- the internally defeated do not triumph. The cure must start with our households and with those in power, with our social values and ties, with the fabric of the family, with the rules and basics of the upbringing of the individual at home, in school, and at university, and then progress to the street (Khalifeh, 2002).

\section{Conclusion}

We can conclude that Sahar Khalifeh maintains that the patriarchal system in the Palestinian community will result in failure. She sees that some kinds of patricide should occur to the patriarchal system of the Palestinian community in order to delete the patriarchal dominion, and subsequently, open the door for the new generation to freely last their resistance and be able to reject the basic patriarchal system, i.e. Israel. The novel shows that the dependent and helpless father symbolizes the patriarchal society of Palestine. So, it is beneficial to notice that the father is also lazy as to say that traditions of Palestinian society make it unable to make progress. Consequently, the clash between Basil, Nuwar and Adil who left the machine in the demolished house is a kind of patricide.

\section{References}

Abrams, M.H. (1999). A Glossary of Literary Terms. Boston: Heinle.

Abu-Shamsieh, E. (1978). Wild Thorns (Al-Sabbar) by Sahar Khalifeh; Trevor LeGassick; Elizabeth Fernea. Arab studies Quarterly, 9 (3), 344-346.

Amireh, A. (1983). Between Complicity and Subversion: Body Politics in Palestinian National Narrative. The South Atlantic Quarterly, 102(4), 747-772.

Becoming a Palestinian writer and feminist: an interview with Sahar Khalifeh. (1983). Off our Backs, 13 (3), 13-33.

Bocock, R. (2002). Sigmund Freud. New York: Routledge.

Ebileeni, M. (2017). Palestinian Writings in the World: A Polylingual Literary Category Between Local and Transnational Realms. Interventions, 19(2), 258-281.

Freud, S. (2001). Totem and Taboo. Translated by James Strachey. New York: Rutledge.

Freud, S. (1939). Moses and Monotheism. Translated by Katherine Jones, London: The Hogarth press and the institute of psycho-analysis.

Heller, S. (2005). Freud A to Z. New Jersey: Wiley.

Haj, S. (1992). Palestinian Women and Patriarchal Relations. Signs, 17(4), 761-778.

Jayyusi, S. K. (1992). Anthology of Modern Palestinian Literature. New York: Columbia university press.

Johnson, P. (1990). Uprising of a novelist: Penny Johnson interviews Sahar Khalifeh. The women's Review of books, 7 (10/11), 24.

Jaber, E. (2009). "A Provocative Writer Who Challenges and Ridicules Authoritarians and Calls for Change, Sahar Khalifeh: My Work is Realist, From People, Towards People." Trans Sami Hanna. Assafir Cultural Supplement, Friday March 27, 2009. Web. Arabic at http://assafir.com/Windows/ArticlePrintFriendly.

Jung, C. G. (1988). Man, and his Symbols, New York: Doubledy.

Khalifeh, S. (2002). My Life, Myself, and the World. In Al-Jadid, 8 (39), Retrieved July15, 2014 from http://www.mafhoum.com/press4/129C31.htm. 
Khalifeh, S. (2005). Wild thorns. Translated by Trevor le Gassick and Elizabeth Fernea. London: Al- Saqi books.

Koudur, P., \& Koudur, S. (2018). The Multiple Resistance Strategies for Survival under Israeli Occupation in the Novels of Sahar Khalifeh.

Lear, J. (2005). Freud. New York: Routledge.

Massad, J. (1995). Conceiving the Masculine: Gender and Palestinian Nationalism. Middle East Journal, 49(3), 467-483.

Sabbagh, S. (1989). Palestinian Women writers and the Intifada. Social Text, 22, 62-78.

Storr, A. (2001). Freud: A very short introduction. New York: Oxford.

Zalman, A. (2002). Gender and the Palestinian Narrative of Return in Two novels By Ghassn Kanafani. The Arab Studies Journal, 10-11(1/2), 17-43. 